\title{
Chapter
}

\section{Exuberance in China's Renewable Energy Investment: \\ Rationality, Capital Structure, and Implications with Firm \\ Level Evidence}

Dayong Zhang

Hong Cao

Peijiang Zou

April 2016

This chapter should be cited as

Zhang, D., H. Cao and P. Zou (2015), 'Exuberance in China's Renewable Energy Investment: Rationality, Capital Structure, and Implications with Firm Level Evidence', in Kimura, S., Y. Chang and Y. Li (eds.), Financing Renewable Energy Development in East Asia Summit Countries. ERIA Research Project Report 2014-27, Jakarta: ERIA, pp.193-222. 


\title{
Chapter 7
}

\section{Exuberance in China's Renewable Energy Investment: Rationality, Capital Structure, and Implications with Firm Level Evidence}

\author{
Dayong Zhang ${ }^{19}$, Hong $\mathrm{CaO}^{20}$ and Peijiang Zou ${ }^{21}$
}

\begin{abstract}
The 21st century has already witnessed phenomenal worldwide growth in renewable energy investments. China has been especially remarkable, surpassing both the US and the EU in 2013. Some recent facts, however, have raised the question of whether China's exuberant investment in renewable energy sector is rational. This study aims to contribute to the literature and to the debate in two ways. First, it tests the over-investment hypothesis based on the mainstream finance methodology (the $Q$ model); second, it analyses the role of capital structure in the performance of China's renewable energy firms. Empirical results could then provide recommendations for policymakers on how to prompt sustainable growth in the renewable energy sector. Although based on China, this study's main findings could also contribute to policy design for emerging economies.
\end{abstract}

Keywords: Renewable energy, over-investment, Tobin's Q, capital structure, China

JEL: Q20, G11

\footnotetext{
19 Corresponding author: Dayong Zhang, Research Institute of Economics and Management, Southwestern University of Finance and Economics, 555 Liutai Avenue, Chengdu, China, 611130. Email: dzhang@swufe.edu.cn

20 Center for Energy and Environmental Policy Research, Beijing Institute of Technology, China and School of Management and Economics, Beijing Institute of Technology, China

21 Research Institute of Economics and Management, Southwestern University of Finance and Economics, China
} 


\section{Introduction}

Since the start of the new century, the world economy has been facing an everincreasing demand for energy and the challenges of climate change. Although opinions still differ, the international community generally believes that global warming is a real threat and that reducing greenhouse gas emissions is necessary. This provides a natural demand for the development of the new energy sector (or clean/renewable energy) in place of traditional forms of fossil fuel energy.

The increasing demand for clean energy has led to a phenomenal growth in global investments in the renewable energy sector (Figure 7.1) over the last 10 years. As reported by Bloomberg New Energy Finance (2014), its average annual growth rate from 2005 to 2013 was approximately $24 \%$. The growth pattern has clearly been more volatile since the 2008-2009 global financial crisis. Although developed countries are still the major contributors to renewable energy investments, developing countries have higher growth rates ( $27 \%$ vs. $15 \%)$ and have begun to catch up. In fact, China surpassed both Europe and the US and became the world's top renewable energy investor in 2013. While European and American investments have been falling since 2011, the continuous growth of China and Asian and Oceanian countries (ASOC), excluding China and India) have shown strong potential.

As one of the biggest energy consumers in the world, China has been active in developing its renewable energy sector. In 2005, the National People's Congress of China passed the Renewable Energy Law (REL). The introduction of REL marked China's renewable energy development moving into the fast lane. Several supporting measures and regulation guidelines have been introduced to stimulate renewable energy development (see Wang et al., 2010; Shen and Luo, 2015; Zhao et al., 2014, for more information). Since then, the total investments in the renewable energy sector have grown rapidly, from \$2.4 billion in 2004 to more than \$59.6 billion in 2012 (Bloomberg New Energy Finance; UNEP). According to the International Renewable Energy Agency (IRENA, 2014), the expansion of China's renewable energy sector has been very aggressive. Apart from its already largest installed capacity of wind and hydroelectric power, China installed more solar photovoltaic (PV) capacity than the whole Europe in 2013. 
Figure 7.1: Global Trend of New Investment in Renewable Energy: 2004-2013 (US\$ billion)

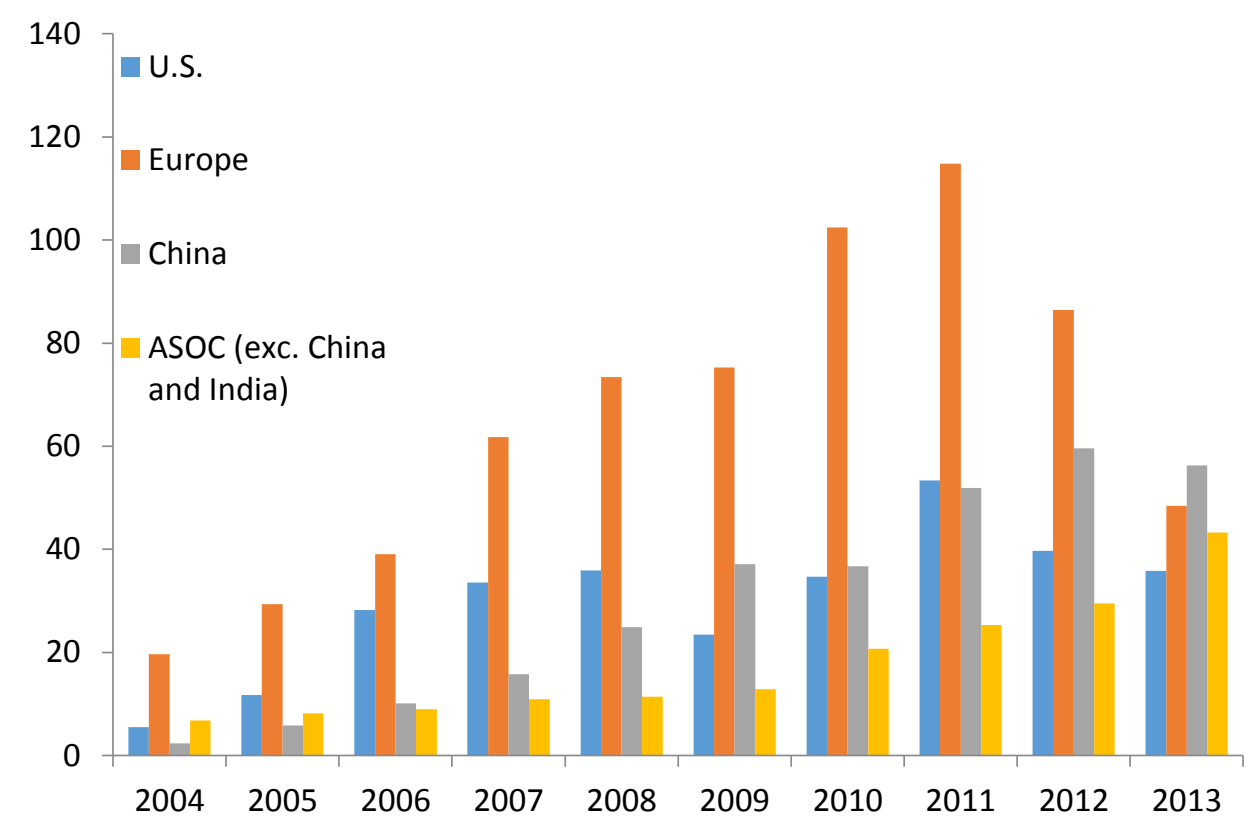

ASOC = Asia and Oceania countries (excluding China and India) $;$ US = United States

Sources: UNEP; Bloomberg New Energy Finance.

The enthusiasm for new energy investments in China has also been driven by mounting environmental pressures. China's greenhouse gas emissions have often been criticised for being one of the primary drivers of the world's increasing aggregates level of emissions (Peters et al., 2013). Policymakers in China have set up clear goals to reduce emissions. However, the size of its economy and its aim for high-speed growth have created a dilemma for the government and made it harder to achieve desired emission levels. Besides, the excessive use of coal (which comprises approximately $70 \%$ of China's energy use) has made the country one of the most polluted areas in the world. Nationwide air quality has continued to worsen, in turn leading to calls for improvements and action against further deterioration.

Another motivation for developing China's renewable energy sector is to ensure energy security (IRENA, 2014a). Behind China's fast economic growth in the last three decades is an increasing demand for energy. China has already become a net energy importer, depending heavily on the international market. Taking crude oil as an example, more than half of the oil that China consumes is imported. Discovering how to meet the increasing energy demand and ensure sustainable growth is of great strategic importance. The increasing needs for energy in the modern society and the exhaustible nature of most 
fossil fuels mean that developing the renewable energy sector and utilising alternative sources of energy are inevitable. In fact, China has abundant renewable energy resources (Shen and Luo, 2015), including hydro, wind, solar, biomass, and geothermal resources, which offer clean power sources and alternatives to fossil fuels. Developing the renewable energy sector is therefore necessary and also feasible to provide stable energy supply to the growing Chinese economy.

Recognising the strategic importance of the renewable energy sector, policymakers in China strongly support the development of renewable energy and have set clear targets. For example, China's 12th Five-Year Plan states that by 2015 and 2020, non-fossil fuel energy should account for $11.4 \%$ and $15 \%$ of the total primary energy consumption, respectively. Investment in the renewable energy sector will continue thriving with government support and subsidies.

Although there is evidence (Zhao et al., 2014) of its many benefits, the boom in renewable energy investments is not without problems. Fast expansion can induce misallocation of resources and unbalanced industrial structure, which exposes the whole sector to high risks. For example, China's solar photovoltaic (PV) industry has experienced rapid growth since 2008 and China is now the world's largest manufacturer of PV products. In 2011, China accounted for approximately $60 \%$ of global PV production. The industry is mainly export driven and depends heavily on the demand of the EU and North American markets. Policy changes in the EU and the US between 2011 and 2012 (reducing subsidies by the EU and imposing anti-dumping tax by both parties) caused sharp drops in market demand and clearly surplus of China's PV industry. It eventually led to a substantial decline in the price of PV products. Similar issues also occurred in the wind power sector in China. Some recent dramatic increases of China's wind power capacity may also be the consequence of possible overinvestment (Liu, 2013).

Investment in the renewable energy sector is risky, as this is a relatively new industry. This is probably why the global trend has been more volatile since the 2008 global financial crisis, potentially causing higher uncertainties in the market. Government subsidies and support can only provide the industry with short-run motivation, but not replace market mechanisms. It is observed that China's energy firms tend to invest irrationally (Tan, 2013). Similar concerns can also be extended to the fast-growing renewable energy sector. If overinvestment exists in this sector, it can cause a significant waste of resources and also 
do harm to the industry's development. Therefore, it is necessary to empirically investigate the story behind China's exuberance towards renewable energy investments.

The first goal of this chapter is therefore to empirically test for the rationality of renewable energy investments in China. 'Irrational exuberance', a phrase used by Greenspan (1996) in a speech given at the American Enterprise Institute during the dotcom bubble of the 1990s, is also used by Shiller (2000) to warn that the market might be overvalued. We borrow the concept here and extend the existing literature on testing for the free cash flow problem (Jensen, 1986) in China's renewable energy sector. Specifically, we use data from listed firms and adopt a standard finance methodology to investigate the overinvestment problem.

The Economic Research Institute for ASEAN and East Asia (2012) estimated that about US\$1.5 trillion would be needed from 2009 to 2035 for investment in renewable energy in the East Asia Summit (EAS) region, providing a very positive outlook on the future of the renewable energy industry's development. The International Renewable Energy Agency (IRENA, 2014b) argues that financing renewable energy is getting easier and cheaper, but still with variations. Figuring out how to finance renewable energy investments at firm level is important not only to the managers, but also to the policymakers. Figure 2 compares new global investments in renewable energy by asset class in 2005 and 2011 (before and after the global financial crisis, respectively). Asset financing remains the major source of investment, accounting for around two-thirds of total investment. This number gets much higher in China where it shows more than $90 \%$ of asset financing (i.e., 95\% in 2013, UNEP, Bloomberg New Energy Finance) and almost no public market and venture capital/private equity $(\mathrm{VC} / \mathrm{PE})$ investments in the renewable energy sector. 
Figure 7.2: New Global Investments in Renewable Energy by Asset Class, 2005 and 2011

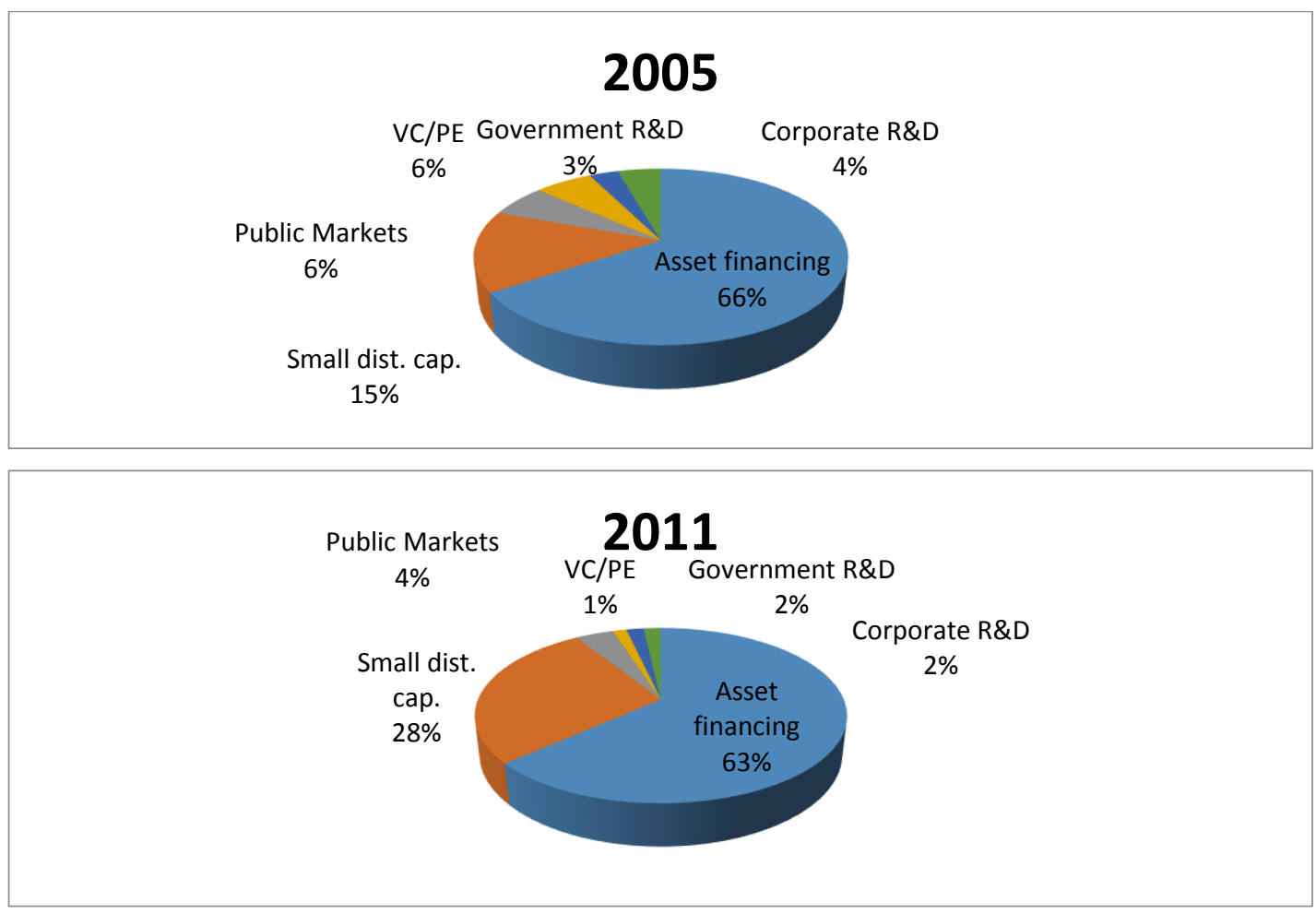

$P E$ = private equity; $R \& D=$ research and development; $V C=$ venture capital.

Sources: UNEP; Bloomberg New Energy Finance.

Zeng et al. (2014) provide a detailed overview of China's renewable energy investment structure and financing channels. They show that bank loans are the main financing channel with a total of CNY300 billion issued by banks by the end of 2011. Equity financing in the stock market has been popular since 2009, and by the end of June 2012 more than CNY20 billion had been raised by listed firms in this sector. The evolving of financing structure has brought an additional question: does capital structure matter in the renewable energy sector? If yes, what is the best form of financing in this industry? Answering these questions is the second main objective of this paper.

The remainder of this chapter is organised as follows. Section 2 provides a brief survey of relevant literature with more focus on introducing the background of renewable energy investments in China. Section 3 introduces the methods used in our empirical studies. Section 4 describes the data and Section 5 reports empirical results and discusses potential implications. The last section concludes. 


\section{Literature review}

\subsection{Renewable energy investment: a financial perspective}

The significance of developing the renewable energy sector has attracted intensive attention in the literature. The world needs to invest heavily in renewable energy development ${ }^{22}$ to reduce emissions and control global warming. The sustainability of such investments requires policymakers and firms to act optimally. Wustenhagen et al. (2007) introduce the concept of social acceptance of renewable energy, pointing to the needs to explore the factors that affect the financial community's acceptance of renewable energy innovation.

Wustenhagen and Menichetti (2012) propose a conceptual framework for renewable energy investment and emphasise the importance of this issue in the background of finance theory. Their starting point is that risk, return, and policy jointly decide the current investment levels. Understanding the market mechanism, especially from the investors' perspective (Dinica, 2006; Hamilton, 2009), is crucial to successful renewable energy investment. One of the key messages from these authors is incorporating financial principles to investigate issues in renewable energy investment. Common factors in finance theory, such as the risk-return relationship, diversification, heterogeneous investors, behavioural finance, and bounded rationality, are all important aspects alongside with policies driving renewable energy investment.

Given the environmental externalities of renewable energy in comparison to other conventional forms, policymakers need to be involved (IPCC, 2011); however, policy alone cannot secure sustainable renewable energy development. Subsidies and support from policymakers may change the risk-return relationship in the renewable energy investment sector and affect investors' behaviour as a result (e.g., De Jager and Rathmann, 2008; Burer and Wustenhagen, 2008). Banerjee (1992) introduces the notion of herding in financial markets. Subjecting investors in the renewable energy sector to herding can result in overinvestment/underinvestment. Due to agency problems (Jensen, 1986), investors and managers may have conflicts of interest, especially when there is policy intervention (which also may result in overinvestment).

22 In 2009 the International Energy Agency (IEA) estimated that around US $\$ 400-500$ billion annually in renewable energy investments would be needed until 2020 
Figure 7.3: Source of Financing in Different Stages of Renewable Energy Development

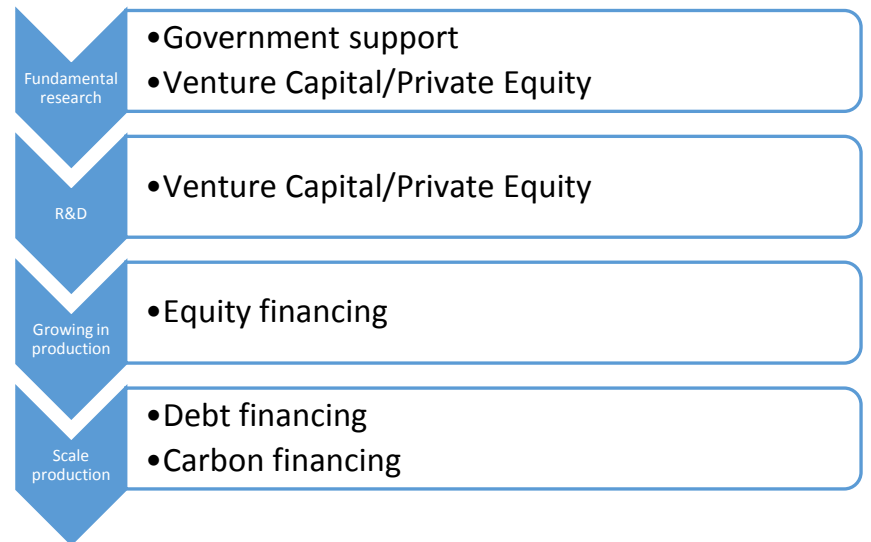

$R \& D=$ research and development.

Source: Complied by the authors.

Another interesting aspect of renewable energy investment is the source of financing. Different sources of financing may be applied to various stages of renewable energy development (Figure 7.3). Grubb (2004) suggests that public funds are needed in the early stages of clean innovation. Private sources are more likely to invest in firms with imminent profitability (Popp, 2010). Olmos et al. (2012) discuss the issue of supporting clean energy innovation via main financing instruments. They suggest that financing options may differ for different stages of innovation.

Different sources of financing raise the important question of whether capital structure matters to renewable energy firms. In the traditional financial theory, Modigliani and Miller's (1958) theorem suggests that capital structure does not matter, meaning that the source of financing cannot affect the firm's value. This relies on a series of strong assumptions, such as market perfection, no taxation, etc. The reality can be more complicated and especially relevant for the renewable energy sector. In fact, different financial instruments have been used in development stages because of financial motivations.

A recent study by Corsatea et al. (2014) on the financial sources and their impacts on Europe's wind energy sector finds that the three main sources of finance are public support for research, development, and demonstration (RD\&D), incentives for the production of wind energy, and access to credit. Their empirical results suggest that corporate debt is the primary factor supporting both wind technology research investments and wind turbine sales (with other sources playing more limited roles). Their study also 
suggests that compared to financial risks, regulatory risks are more influential.

\subsection{Renewable energy investment in China}

The recent surge in renewable energy investment in China and the strong government support for the sector's development have drawn considerable attention in the literature. Most of these works focus on one field, such as wind energy (for example, Wang, 2010; Zeng et al., 2013; Liu, 2013; Caralis et al., 2014) or solar energy (Zhao et al., 2011; Zhang et al., 2014; Zhao et al., 2015).

Liu (2013) builds a simple model to explore why firms may overinvest in wind power capacity. Firms have incentives to invest more since the additional (overinvested) part has value for holding scarce resources for future purposes. Zhao et al. (2011) provide an overview of the development of the solar PV industry in China. This industry has grown rapidly due to strong support from both the central and local governments. Expansion and speed may result in overinvestment. Caralis et al. (2014) evaluate the profitability of wind energy investment in China through Monte Carlo simulation. Lin and Yang (2014) measure the efficiency of the power industry in China and suggest that this industry's investment structure reform can improve efficiency. Zhang et al. (2014) evaluate the renewable energy policies of China's solar PV power generation sector via a real option model. Their results show an imbalance between government subsidies and investors' interests.

Wang et al. (2010) analyse China's renewable energy policies since the passing of REL in 2005. One of their concerns is that the current renewable energy generators have a low level of efficiency and a significant amount of waste. Zeng et al. (2014) provide a detailed overview of the current status of China's renewable energy investments and financing. They describe the current situation of general investment in renewable energy, investors, financing sources, and channels. Their study also discusses investment and financing issues and countermeasures via a comparative analysis based on the wind and photovoltaic power sector. In general, most of these existing studies about China are descriptive, providing readers with very important information and raising a series of interesting research questions. 


\section{Methodology}

To answer the aforementioned questions, namely overinvestment and the role of capital structure, we take an empirical approach that follows mainstream financial literature. To avoid data availability constraints that negatively impact proper empirical research, we use publicly listed firms' information in our econometric models. Although publicly listed firms only reflect a fraction of the renewable energy industry, their size and importance are more relevant to policymakers. The development of the renewable energy industry will inevitably go through a process of restructuring and consolidation. Those key players will dominate the market and steer the direction of this industry. Therefore, evaluating the performance of these listed firms can provide critical information. Furthermore, regulations require these firms to make their financial and operational information publicly available, which is essential to our empirical modelling. The econometric models are given as follows.

\subsection{Testing for overinvestment}

A firm's decision to invest in a project often depends on its future profitability. Standard financial theory suggests that a rational investment decision requires that the project offers a future stream of cash flows that will generate positive net present value (NPV). Due to agency problems or other irrational managerial behaviour, especially when firms have free cash flows (FCF( Jansen, 1986), however, they tend to invest in negative NPV projects or overinvest. In other words, managers have strong incentives to invest rather than distribute the FCF as dividends, even when the investment opportunities are poor (with negative NPV).

Since the return on investment will be lower than the cost of capital, these investments will be at the expense of the shareholders. The rise of the FCF problem was against the backdrop of the 1970 s oil crisis. Radical changes in crude oil prices generated significant free cash flows in the oil industry. As Jensen (1986) points out: 'The 1984 cash flows of the ten largest oil companies were US\$48.5 billion, $28 \%$ of the total cash flows of the top 200 firms in Dun's Business Month survey.' The managers of these firms did not pay dividends to the shareholders; instead, they spent heavily on exploration and development (E\&D) as well as diversification programmes to invest outside of the oil industry. McConnell and Muscarella (1986) find that these expenditures reduced firms' stock prices. It is also 
shown that the recovery rates for these investments only ranged from $60 \%$ to $90 \%$.

To test the FCF hypothesis, it is important to first justify the firms' future investment opportunities. Empirically, Lang and Litzenberger (1989) propose to use Tobin's Q, the ratio of the market value of the firm's assets to their replacement cost, to distinguish between good and bad investment opportunities. The good opportunities also refer to projects with positive NPV. It is often said that a higher Tobin's $Q$ indicates good opportunities and more productive investments, thus increasing market value. The model can be set as:

$$
\mathrm{I}_{\mathrm{i}, \mathrm{t}} / \mathrm{K}_{\mathrm{i}, \mathrm{t}-1}=\beta_{1} \mathrm{TQ}_{\mathrm{it}-1}+\beta_{2}\left(\mathrm{CF}_{\mathrm{i}, \mathrm{t}} / \mathrm{K}_{\mathrm{i}, \mathrm{t}-1}\right)+\mu_{\mathrm{i}}+\gamma_{\mathrm{t}}+\varepsilon_{\mathrm{i}, \mathrm{t}}
$$

Where $\mathrm{I}_{\mathrm{i}, \mathrm{t}} / \mathrm{K}_{\mathrm{i}, \mathrm{t}-1}$ stands for the investment divided by the beginning-of-period capital stock, $\left(\mathrm{CF}_{\mathrm{i}, \mathrm{t}} / \mathrm{K}_{\mathrm{i}, \mathrm{t}-1}\right)$ stands for the cash flow scaled by the same capital stock, and $\mathrm{TQ}_{\mathrm{it}}$ is the proxy for investment opportunities. This model also allows for the firm-specific and time-specific fixed effects through $\mu_{\mathrm{i}}$ and $\gamma_{\mathrm{t}}$. According to the above specification, Lang et al. (1991) propose using Tobin's Q as a proxy for investment opportunities and they set unit value as a threshold to test for the overinvestment (or free cash flow) hypothesis. For firms with a high Tobin's $Q$ ( $T Q>1$ ), they are considered to be good investment opportunities. Adding more control variables Z, the empirical model can be set up:

$$
\mathrm{I}_{\mathrm{i}, \mathrm{t}} / \mathrm{K}_{\mathrm{i}, \mathrm{t}-1}=\beta_{1} \mathrm{TQ}_{\mathrm{i}, \mathrm{t}-1}+\beta_{2} \frac{\mathrm{CF}_{\mathrm{i}, \mathrm{t}}}{\mathrm{K}_{\mathrm{i}, \mathrm{t}-1}}+\beta_{3}\left[\frac{\mathrm{CF}_{\mathrm{i}, \mathrm{t}}}{\mathrm{K}_{\mathrm{it}-1}} \times \mathrm{I}\left(\mathrm{TQ}_{\mathrm{it}-1}<1\right)\right]+\delta \mathrm{Z}_{\mathrm{it}-1}+\mu_{\mathrm{i}}+
$$

$\gamma_{\mathrm{t}}+\varepsilon_{\mathrm{it}}$

Where II $(\cdot)$ is a function that equals unit when the statement in the brackets is true and zero otherwise. The key indicator here is $\beta 3$. If positive, it means that firms with lower investment opportunities will invest their cash flows; this suggests FCF problems or general irrational investments in China's renewable energy sector. Since there are lagging dependent variables, the dynamic panel data model (DPD) estimation (developed by Arellano and Bond [1991], Arellano and Bover [1995], and Blundell and Bond [1998]) will be adopted and estimated through the system GMM method.

One challenge for this test is finding the right proxy for future growth opportunities. Although TQ is a simple choice, it has been criticised (by Gilchrist and Himmelberg, 1995, for example) for being an inappropriate proxy. In our data, the average is 1.9 and majority of firms have TQs higher than 1 . The renewable energy sector has probably been considered as having potential to grow, and the market prices are abnormally high (overvaluation). In this sense, using Tobin's $Q$ is not feasible. To solve this problem, we use 
the growth rate of operational income as an alternative proxy, and consider the last period of operational income growth as a future growth opportunity. Similar proxies can also be found in Ding et al. (2010), who use sales growth in their empirical model.

\subsection{The role of capital structure}

Deciding how to finance renewable energy projects is also an important issue for policymakers. It is worth examining whether different sources of finance can have an impact on the success of investments. According to standard financial theory (Moligliani and Miller, 1958), capital structure does not matter. This result relies on the strong assumption of a perfect market, something that remains elusive in the real world. The source of financing (or capital structure) can also affect renewable energy investments and performance (see Corsatea et al., 2014, for example). Our study will follow this basic idea, but focus more on the renewable energy sector where firms' capital structure and other factors will be included in our regression analysis to identify their relative roles.

The main measure of a capital structure is the debt-to-asset ratio (total liabilities divided by total assets). To further investigate the detailed structure, we consider current liabilities and non-current liabilities separately, and the sources of debts (e.g. bank loans, corporate bonds) separately. The impact of capital structure on a firm's profitability results in the following econometric model:

$$
\mathrm{ROA}_{\mathrm{it}}=\beta_{1} \mathrm{D}_{\mathrm{it}}+\delta \mathrm{Z}_{\mathrm{it}-1}+\mu_{\mathrm{i}}+\gamma_{\mathrm{t}}+\varepsilon_{\mathrm{it}}
$$

where ROA denotes return on assets, which measures a firm's profitability; $D$ is the measure of capital structure, for example, the debt asset ratio; $Z$ is a vector of control variables; firm-specific and time-specific fixed effects are captured by $\mu_{\mathrm{i}}$ and $\nu_{\mathrm{t}}$.

\section{Data}

The data in this study were collected from the RESSET financial research database. ${ }^{23}$ Using information from the three main financial media collections ${ }^{24}$ and checking them carefully (similar to Broadstock et al, 2012), we have identified a total of 106 firms, which

\footnotetext{
$23 \mathrm{http}: / /$ www1.resset.cn.

24 They are Sina finance, Ifeng finance, and http://www.china-nengyuan.com/ssgs/, respectively.
} 
got listed between 1990 and 2012, specialising in four fields (wind, nuclear, ${ }^{25}$ biomass, and solar energy). Studying listed firms may limit the implications of our results, but the benefits are clearly significant. First, there is very intensive information available for this empirical study. Second, these firms represent the main players in the development of China's renewable energy sector and their behaviour can have profound impacts on the industry relative to other smaller firms.

The distribution of these firms and years of their initial public offering (IPO) are reported in Table 7.1. Given other financial variables and our sample size, the effective sample in our study spans 13 years, from 2001 to 2013 (unbalanced panel). These firms are further divided according to their main business' stage of production (position in the industrial chain). Seventy-one of them specialise in producing materials and equipment (upstream), 17 are generators/final users (downstream), and the remaining 18 firms have both businesses (mixed).

Table 7.1: Distribution of Renewable Energy Firms

\begin{tabular}{llllll}
\hline Listed Time & Number of Firms & Wind & Nuclear & Biomass & Solar \\
\hline $1990-1999$ & 38 & 15 & 8 & 10 & 9 \\
$2000-2005$ & 26 & 9 & 10 & 2 & 9 \\
$2006-2010$ & 34 & 8 & 12 & 2 & 13 \\
$2011-2012$ & 8 & 1 & 0 & 1 & 6 \\
Total & 106 & 33 & 30 & 15 & 37 \\
\hline
\end{tabular}

Note: Due to duplicate operations, the total number of firms is smaller than the aggregate number in each field.

Sources: RESSET database and authors' calculation.

Following the explanation in section 3, we have constructed key explanatory variables and reported them in Table 7.2. The construction of these variables and their definitions are similar to Lang et al. (1991). More descriptive statistics for firms in each field/stage of their main business are provided in the appendix.

\footnotetext{
25 Nuclear is not normally considered as renewable energy source. However, our paper adopts a more general concept of renewable energy as compared to the traditional fossil fuel energy sector and therefore includes nuclear sector. We thank the comments and concerns raised by the ERIA work group meeting.
} 
Table 7.2: Variable Definition and Descriptive Statistics

\begin{tabular}{llllll}
\hline Variable & \multicolumn{1}{c}{ Description } & Mean & SD. & Min & Max \\
\hline IK & Investment capital (fixed assets) ratio & 0.53 & 1.25 & 0.00 & 17.27 \\
CFK & Cash flows scaled by fixed assets & 0.43 & 0.84 & -1.85 & 10.88 \\
OCF & Operation net cash flow scaled by fixed assets & 0.13 & 1.05 & -12.47 & 9.73 \\
DTA & Total liabilities divided by total assets & 0.62 & 0.30 & 0.08 & 3.00 \\
CTA & Current liabilities divided by total assets & 0.47 & 0.25 & 0.07 & 2.88 \\
NCTA & Non-current liabilities divided by total assets & 0.15 & 0.18 & 0.00 & 1.59 \\
SLTA & Short term loan divided by total assets & 0.18 & 0.14 & 0.00 & 0.72 \\
LLTA & Long term loan divided by total assets & 0.12 & 0.17 & 0.00 & 1.59 \\
BTA & Bond divided by total assets & 0.02 & 0.05 & 0.00 & 0.58 \\
CRTA & Commercial credit divided by total assets & 0.20 & 0.20 & 0.00 & 2.65 \\
SZ & Natural logarithm of total assets (RMB Yuan) & 21.97 & 1.23 & 19.20 & 26.21 \\
ROA & Net profit divided by total assets & 0.03 & 0.05 & -0.37 & 0.35 \\
OIG & Growth rate of operational income & 0.15 & 0.32 & -1.56 & 2.20 \\
AGE & How long the firm has been listed (years) & 8.69 & 4.94 & 1.00 & 24.00 \\
State & Shares owned by state (\%) & 16.49 & 23.77 & 0.00 & 88.58 \\
FOWN & Shares of the largest shareholder (\%) & 36.96 & 15.50 & 3.62 & 73.67 \\
\hline NOte: & Fnt & & & & \\
\hline
\end{tabular}

Note: Investment is defined as cash paid for the construction of fixed assets, intangible assets, and other longterm assets. Cash flow is defined as operating profits plus depreciation of fixed assets. Sources: RESSET database and authors' calculation.

Figure 7.4 plots the annual average of investment capital ratio (IK) across sample firms. It is clear that the passage of REL in 2005 (actually implemented in 2006 in conjunction with a series of favourable policies) marked a booming period of investment starting in 2007. Although the global financial crisis depressed the investment capital ratio shortly thereafter, it remained at a relatively high level until 2012 when both the international environment and domestic development cooled down. The question here was whether this booming period indicated overinvestment in China's renewable energy sector; in other words, were these firms being rational? 
Figure 7.4: Investment Trend of Sample Firms (Annual Average Scaled by Capital, IK)

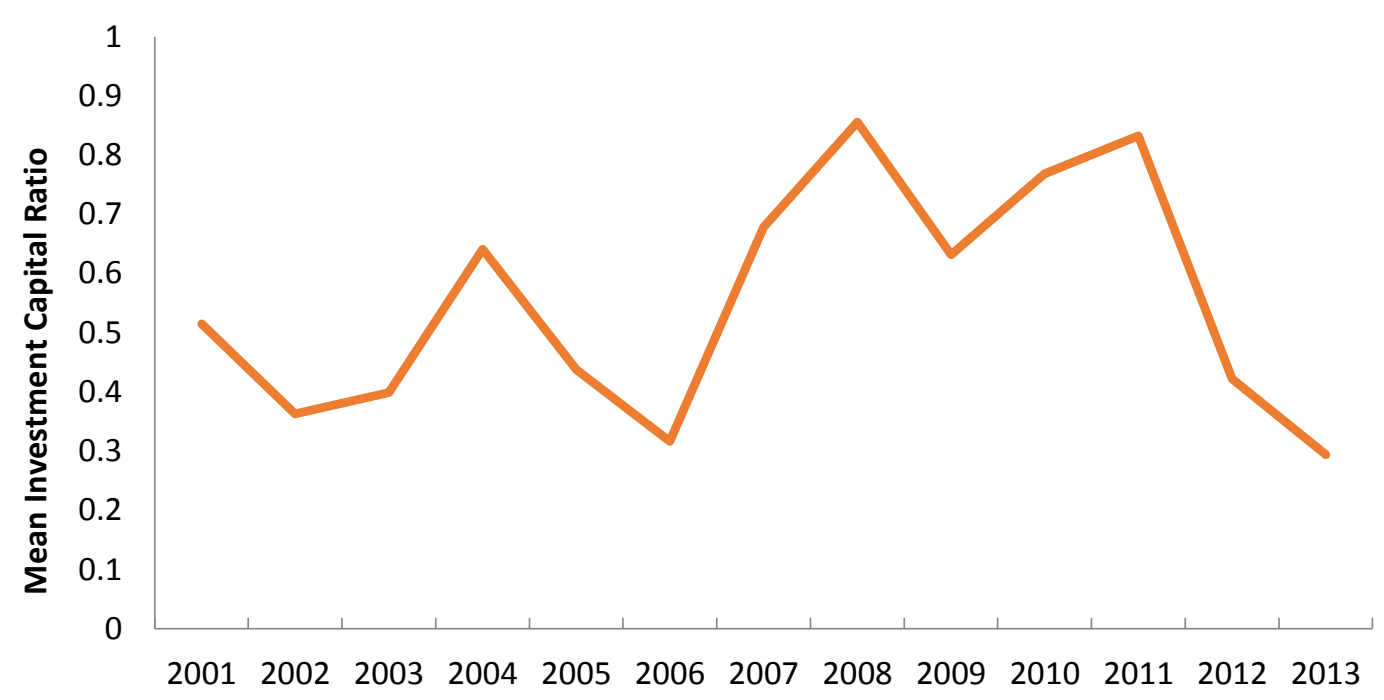

Sources: RESSET database and authors' calculation.

Further information from the four sectors (Figure 7.5) shows that the investment trend differs significantly. For example, in 2007 the biomass sector experienced a significant increase in investment capital ratio. Such dramatic changes may not reflect the market dynamics; rather they may signal that government policies have a strong influence on firms' investment decisions. Since the REL, an intensive set of policies related to the bio-energy sector in China were introduced in 2006 and 2007. For example, China's Department of Agriculture introduced the Agricultural Biological Mass Energy Industrial Development Program (2007-2015) in 2007 (see Zhang et al., 2009; Qiu et al., 2012, for more information). Of course, more formal analysis is needed to provide further information. 
Figure 7.5: Trend of Investment (Annual Average Scaled by Capital, IK) in Sample Firms of Each Sector

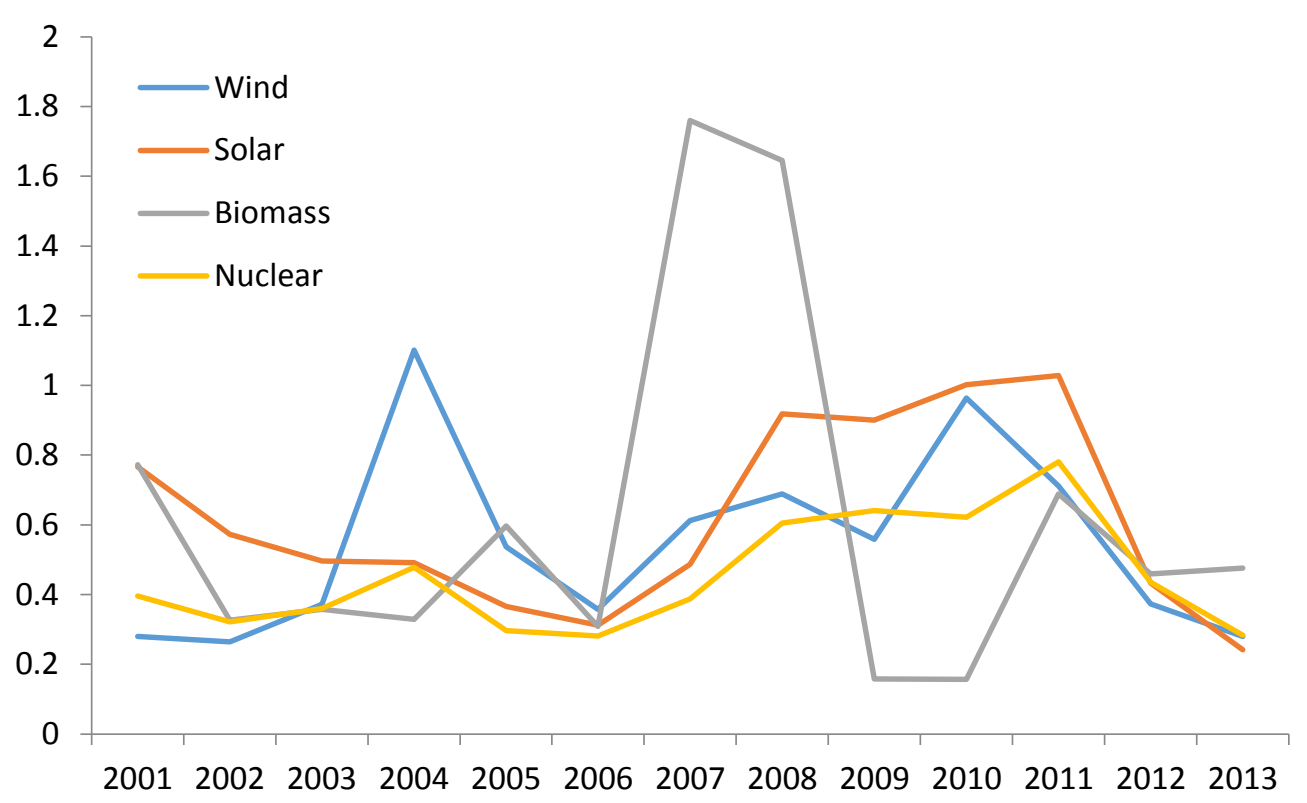

Sources: RESSET database and authors' calculation.

\section{Empirical results and implications}

\subsection{Testing for the overinvestment hypothesis}

Given the econometric model setup discussed in section 3, we report the results for testing the overinvestment hypothesis in Table 7.3. All regressions are estimated using the system Generalized Method of Moments (GMM) method. There are six models listed for comparison, including industrial dummies and time dummies. The first interesting points across all models are the time dummies. They are roughly consistent with the illustrations in Figures 7.4 and 7.5. 
Table 7.3: Testing for Overinvestment Hypothesis

\begin{tabular}{|c|c|c|c|c|c|c|}
\hline & Model (1) & Model(2) & Model(3) & Model (4) & Model (5) & Model (6) \\
\hline $\mathrm{IK}(\mathrm{t}-1)$ & $\begin{array}{l}0.1936^{* *} \\
(0.0885)\end{array}$ & $\begin{array}{l}0.4175^{* * *} \\
(0.0981)\end{array}$ & $\begin{array}{l}0.4071^{* * *} \\
(0.1384)\end{array}$ & $\begin{array}{l}0.3358 * * * \\
(0.0708)\end{array}$ & $\begin{array}{l}0.3351 * * * \\
(0.0842)\end{array}$ & $\begin{array}{l}0.3481^{* * *} \\
(0.0729)\end{array}$ \\
\hline CFK & $\begin{array}{l}-0.1128 \\
(0.1371)\end{array}$ & $\begin{array}{l}0.1388 \\
(0.2482)\end{array}$ & $\begin{array}{l}0.1947 \\
(0.3816)\end{array}$ & $\begin{array}{l}0.1632 \\
(0.2077)\end{array}$ & $\begin{array}{l}0.0900 \\
(0.1007)\end{array}$ & $\begin{array}{l}-0.0062 \\
(0.0886)\end{array}$ \\
\hline OIG $(t-1)$ & & & & $\begin{array}{l}-0.3954 \\
(0.2955)\end{array}$ & $\begin{array}{l}-0.2766 \\
(0.2338)\end{array}$ & $\begin{array}{l}0.1048 \\
(0.2472)\end{array}$ \\
\hline $\mathrm{CFK}^{*} \mathrm{I}(\mathrm{OIG}(\mathrm{t}-1)<0)$ & & & & & $\begin{array}{l}0.5051 * * * \\
(0.1824)\end{array}$ & \\
\hline Inter_Nuclear & & & & & & $\begin{array}{l}-0.4840 \\
(0.8954)\end{array}$ \\
\hline Inter_Biomass & & & & & & $\begin{array}{l}2.8229 * \\
(1.4968)\end{array}$ \\
\hline Inter_Solar & & & & & & $\begin{array}{l}-0.9100 \\
(2.0167)\end{array}$ \\
\hline Inter_Wind & & & & & & $\begin{array}{l}0.8376^{* * *} \\
(0.2606)\end{array}$ \\
\hline$S Z(t-1)$ & & $\begin{array}{l}0.2731 \\
(0.2069)\end{array}$ & $\begin{array}{l}0.3903 \\
(0.4320)\end{array}$ & $\begin{array}{l}0.1495 \\
(0.2458)\end{array}$ & $\begin{array}{l}0.1191 \\
(0.1835)\end{array}$ & $\begin{array}{l}0.1644 \\
(0.1585)\end{array}$ \\
\hline DTA $(t-1)$ & & $\begin{array}{l}-1.2498 * * * \\
(0.4712)\end{array}$ & $\begin{array}{l}-1.4225^{* *} \\
(0.6373)\end{array}$ & $\begin{array}{l}-1.0725 \\
(1.0791)\end{array}$ & $\begin{array}{l}-0.8225 \\
(1.0257)\end{array}$ & $\begin{array}{l}-1.1648 \\
(0.8036)\end{array}$ \\
\hline YD_2002 & $\begin{array}{l}0.0420 \\
(0.1030)\end{array}$ & $\begin{array}{l}0.2936 \\
(0.2586)\end{array}$ & $\begin{array}{l}0.3025 \\
(0.6806)\end{array}$ & $\begin{array}{l}0.1664 \\
(0.2566)\end{array}$ & $\begin{array}{l}0.2244 \\
(0.2537)\end{array}$ & $\begin{array}{l}0.1605 \\
(0.3280)\end{array}$ \\
\hline YD_2003 & $\begin{array}{l}0.1495 \\
(0.1371)\end{array}$ & $\begin{array}{l}0.4650 * * \\
(0.2367)\end{array}$ & $\begin{array}{l}0.4567 \\
(0.7025)\end{array}$ & $\begin{array}{l}0.3285 \\
(0.2627)\end{array}$ & $\begin{array}{l}0.3369 \\
(0.2420)\end{array}$ & $\begin{array}{l}0.2279 \\
(0.3069)\end{array}$ \\
\hline YD_2004 & $\begin{array}{l}0.2807 \\
(0.2482)\end{array}$ & $\begin{array}{l}0.5848 * * \\
(0.2416)\end{array}$ & $\begin{array}{l}0.5170 \\
(0.9594)\end{array}$ & $\begin{array}{l}0.4901 \\
(0.3420)\end{array}$ & $\begin{array}{l}0.4488 \\
(0.2794)\end{array}$ & $\begin{array}{l}0.3515 \\
(0.4331)\end{array}$ \\
\hline YD_2005 & $\begin{array}{l}0.0731 \\
(0.1085)\end{array}$ & $\begin{array}{l}0.3710 \\
(0.2775)\end{array}$ & $\begin{array}{l}0.4762 \\
(0.4735)\end{array}$ & $\begin{array}{l}0.2615 \\
(0.2846)\end{array}$ & $\begin{array}{l}0.2211 \\
(0.2000)\end{array}$ & $\begin{array}{l}0.0595 \\
(0.2563)\end{array}$ \\
\hline YD_2006 & $\begin{array}{l}-0.0114 \\
(0.1166)\end{array}$ & $\begin{array}{l}0.3311 \\
(0.2504)\end{array}$ & $\begin{array}{l}0.3400 \\
(0.4632)\end{array}$ & $\begin{array}{l}0.2246 \\
(0.2881)\end{array}$ & $\begin{array}{l}0.1651 \\
(0.1820)\end{array}$ & $\begin{array}{l}0.1028 \\
(0.1999)\end{array}$ \\
\hline YD_2007 & $\begin{array}{l}0.4010 \\
(0.2882)\end{array}$ & $\begin{array}{l}0.7542 * * \\
(0.3653)\end{array}$ & $\begin{array}{l}0.6949 \\
(0.5985)\end{array}$ & $\begin{array}{l}0.6075 \\
(0.5362)\end{array}$ & $\begin{array}{l}0.5026 \\
(0.3551)\end{array}$ & $\begin{array}{l}0.4504^{*} \\
(0.2431)\end{array}$ \\
\hline YD_2008 & $\begin{array}{l}0.5597 * * \\
(0.2342)\end{array}$ & $\begin{array}{l}0.6594 * * \\
(0.2602)\end{array}$ & $\begin{array}{l}0.5832 \\
(0.4789)\end{array}$ & $\begin{array}{l}0.5515^{*} \\
(0.3145)\end{array}$ & $\begin{array}{l}0.5012 * * \\
(0.1997)\end{array}$ & $\begin{array}{l}0.5182 * * \\
(0.2023)\end{array}$ \\
\hline YD_2009 & $\begin{array}{l}0.3581 * \\
(0.2145)\end{array}$ & $\begin{array}{l}0.3475 \\
(0.2139)\end{array}$ & $\begin{array}{l}0.3167 \\
(0.2821)\end{array}$ & $\begin{array}{l}0.2809 * * \\
(0.1209)\end{array}$ & $\begin{array}{l}0.2735^{*} \\
(0.1456)\end{array}$ & $\begin{array}{l}0.2178 \\
(0.2568)\end{array}$ \\
\hline YD_2010 & $\begin{array}{l}0.4042^{* * *} \\
(0.1234)\end{array}$ & $\begin{array}{l}0.4657^{* * *} \\
(0.1532)\end{array}$ & $\begin{array}{l}0.4300 * \\
(0.2496)\end{array}$ & $\begin{array}{l}0.3188 * * \\
(0.1533)\end{array}$ & $\begin{array}{l}0.2655^{* *} \\
(0.1184)\end{array}$ & $\begin{array}{l}0.3206^{* *} \\
(0.1341)\end{array}$ \\
\hline YD_2011 & $\begin{array}{l}0.3544^{* * *} \\
(0.1177)\end{array}$ & $\begin{array}{l}0.4806 * * * \\
(0.1544)\end{array}$ & $\begin{array}{l}0.4362^{*} \\
(0.2343)\end{array}$ & $\begin{array}{l}0.4174 * * \\
(0.1657)\end{array}$ & $\begin{array}{l}0.3380 * * * \\
(0.1110)\end{array}$ & $\begin{array}{l}0.2942^{* *} \\
(0.1247)\end{array}$ \\
\hline YD_2012 & $\begin{array}{l}0.0549 \\
(0.0457)\end{array}$ & $\begin{array}{l}0.1565 \\
(0.1076)\end{array}$ & $\begin{array}{l}0.1199 \\
(0.1381)\end{array}$ & $\begin{array}{l}0.2195 \\
(0.1347)\end{array}$ & $\begin{array}{l}0.2312 * * \\
(0.0975)\end{array}$ & $\begin{array}{l}0.0671 \\
(0.1278)\end{array}$ \\
\hline Constant & $\begin{array}{l}0.2078 * * * \\
(0.0773)\end{array}$ & $\begin{array}{l}-5.3988 \\
(4.4208)\end{array}$ & $\begin{array}{l}-8.1331 \\
(9.8943)\end{array}$ & $\begin{array}{l}-2.7043 \\
(5.2837)\end{array}$ & $\begin{array}{l}-2.2471 \\
(3.8947)\end{array}$ & $\begin{array}{l}-3.2175 \\
(3.5819)\end{array}$ \\
\hline Industrial dummy & & & $Y$ & Y & $Y$ & $Y$ \\
\hline Observations & 763 & 763 & 763 & 708 & 708 & 708 \\
\hline Number of firms & 105 & 105 & 105 & 103 & 103 & 103 \\
\hline Sargan test & 48.09 & 57.58 & 50.47 & 75.83 & 75.09 & 64.56 \\
\hline Sargan_pvalue & 0.0194 & 0.0127 & 0.0264 & 0.0172 & 0.0157 & 0.0555 \\
\hline
\end{tabular}

Note: Robust standard errors are in brackets. *** denotes $1 \%$ significance, ${ }^{* *}$ for $5 \%$ and $*$ for $10 \%$. It is worth noting that our sample is unbalanced. Some variables (especially financial variables) are missing for some firms, therefore, the effective sample (and number of firms) used in each regression differ from each other. YD refers to year dummies. Please refer to table 7.2 for the definition of other variables.

Source: Prepared by the authors. 
Clearly, investments in the renewable energy sector were significantly higher between 2007 and 2011. The second consistent finding across all models is the positive first-order autoregressive component. The coefficients on lagged investment capital ratio are all positive and significant at $1 \%$ level. It suggests that investment in China's renewable energy sector had very strong momentum during the sample period. This is, of course, consistent with the fact that China's overall investment in the renewable energy sector has been continuously increasing.

Debt ratio has been negatively related to firm investments as given in models (2) and (3), indicating a potential constraint to firms' investment decisions as the liability level increases the risk of insolvency. This effect disappears after growth opportunity is controlled. Firm size is positively associated with investment, though the coefficients are generally not significant.

The main testing results on overinvestment hypothesis can be found in models (5) and (6). Lagged OIG (representing growth opportunities) are generally insignificant, but the coefficients on interaction term $\left.\mathrm{CFK}^{*} \mathrm{I}(\mathrm{OIG}(\mathrm{t}-1)<)\right)^{26}$ are significant and positive. The positive autoregressive part of investments may contribute to the insignificant relationship between growth opportunities and investment, but the significant positive coefficient on the interaction term clearly indicates that firms with fewer opportunities (but positive cash flows) tend to invest more. Consistent with Jensen's (1986) free cash flow hypothesis, firms tend to overinvest when the project they have may not be profitable, corresponding to the irrational behaviour of managers.

When we dissect the interaction term according to sectors, namely nuclear, wind, biomass and solar, the results show clear evidence that overinvestment differs significantly across sectors. The biomass coefficient is 2.8229 and the wind coefficient is 0.8376 , both of which are statistically significant. Overinvestment and irrationality exist in these two sectors and are supported by our results. The conclusion of the nuclear and solar sectors is not so obvious.

It is important to be cautious when interpreting these results. Those interaction terms correspond to testing for free cash flow hypothesis; this means that firms with free

26 We have also performed similar analysis using Tobin's $Q$. The results, as expected due to the limited number of $Q$ being smaller than unit, are generally not significant and uninformative. Therefore, we do not report those results in this study. 
cash flows but bad investment opportunities are still willing to invest. It is certainly irrational that managers should represent shareholders' best interests. Even without free cash flow problems (such as solar/nuclear), these firms can still aggressively invest as the industry shows strong upward trends (justified by the positive autoregressive term). The annual dummy effects have also shown a strong investment trend, generally in the renewable energy sector.

\subsection{The role of capital structure in profitability}

We have learned from financial theory that capital structure is relevant in a world with frictions such as the tax benefits of debt over equity, cost of bankruptcy, etc. It is therefore important to study how capital structure in China's renewable energy sector affects its performance. This part studies a series of financing instruments and their relative importance to a firm's capital structure. Starting from the standard debt equity ratio, or debt-to-asset ratio, as the total value of a firm's assets equals debt plus equity, we also studied the impacts of other forms of debts, such as current liabilities, non-current liabilities, total loans, corporate bonds, commercial credit, short-term loans, and long-term loans. The estimation results of a series of alternative models are reported in Table 7.4. All these models are estimated using fixed effect specification with yearly dummies included. To control for other firm-specific effects, the growth rate of operational income, size of the firm, and age of the firm are also included. The main explanatory variables have been delayed one period to reflect the fact that the previous period's decisions can affect this period's output. Using time delays also enables us to avoid endogeniety. 
Table 7.4: The Role of Capital Structure

\begin{tabular}{|c|c|c|c|c|c|c|}
\hline & Model (1) & Model (2) & Model (3) & Model (4) & Model (5) & Model (6) \\
\hline \multirow[t]{2}{*}{ DTA(t-1) } & 0.0145 & & & 0.0133 & & \\
\hline & $(0.0095)$ & & & $(0.0093)$ & & \\
\hline \multirow[t]{2}{*}{$\mathrm{CTA}(\mathrm{t}-1)$} & & 0.0101 & & & 0.0085 & \\
\hline & & $(0.0116)$ & & & $(0.0108)$ & \\
\hline \multirow[t]{2}{*}{$\operatorname{NCTA}(\mathrm{t}-1)$} & & 0.0246 & & & 0.0240 & \\
\hline & & $(0.0166)$ & & & $(0.0161)$ & \\
\hline \multirow[t]{2}{*}{$\mathrm{BTA}(\mathrm{t}-1)$} & & & 0.0143 & & & 0.0140 \\
\hline & & & $(0.0381)$ & & & $(0.0378)$ \\
\hline \multirow[t]{2}{*}{$\operatorname{CRTA}(\mathrm{t}-1)$} & & & $0.0597 * *$ & & & $0.0589 * *$ \\
\hline & & & (0.0239) & & & $(0.0245)$ \\
\hline \multirow[t]{2}{*}{ SLTA(t-1) } & & & $-0.0467 * *$ & & & $-0.0489 * *$ \\
\hline & & & $(0.0228)$ & & & $(0.0212)$ \\
\hline \multirow[t]{2}{*}{$\operatorname{LLTA}(\mathrm{t}-1)$} & & & 0.0190 & & & 0.0192 \\
\hline & & & $(0.0152)$ & & & $(0.0144)$ \\
\hline \multirow[t]{2}{*}{ OIG $(t-1)$} & $0.0306 * * *$ & $0.0310^{* * *}$ & $0.0255^{* * *}$ & $0.0303 * * *$ & $0.0308^{* * *}$ & $0.0249 * * *$ \\
\hline & $(0.0076)$ & $(0.0077)$ & $(0.0080)$ & $(0.0076)$ & $(0.0077)$ & $(0.0079)$ \\
\hline \multirow[t]{2}{*}{ Age } & $0.0025 *$ & $0.0024 *$ & 0.0022 & $0.0032 * *$ & $0.0031 * *$ & $0.0030 * *$ \\
\hline & $(0.0014)$ & $(0.0014)$ & $(0.0014)$ & $(0.0013)$ & $(0.0013)$ & $(0.0013)$ \\
\hline \multirow[t]{2}{*}{ State } & & & & 0.0001 & 0.0001 & 0.0001 \\
\hline & & & & $(0.0002)$ & $(0.0002)$ & $(0.0002)$ \\
\hline \multirow[t]{2}{*}{ FOWN } & & & & 0.0003 & 0.0004 & 0.0004 \\
\hline & & & & $(0.0005)$ & $(0.0005)$ & $(0.0005)$ \\
\hline \multirow[t]{2}{*}{$S Z$} & $-0.0221 * * *$ & $-0.0224 * * *$ & $-0.0234 * * *$ & $-0.0228 * * *$ & $-0.0232 * * *$ & $-0.0244 * * *$ \\
\hline & $(0.0061)$ & $(0.0062)$ & $(0.0062)$ & $(0.0062)$ & $(0.0063)$ & $(0.0061)$ \\
\hline \multirow[t]{2}{*}{ YD_2003 } & 0.0136 & 0.0135 & 0.0149 & 0.0130 & 0.0129 & 0.0143 \\
\hline & (0.0104) & (0.0104) & $(0.0101)$ & (0.0107) & (0.0107) & (0.0104) \\
\hline \multirow[t]{2}{*}{ YD_2004 } & 0.0064 & 0.0064 & 0.0045 & 0.0059 & 0.0059 & 0.0040 \\
\hline & $(0.0115)$ & $(0.0115)$ & $(0.0116)$ & $(0.0118)$ & $(0.0118)$ & $(0.0119)$ \\
\hline \multirow[t]{2}{*}{ YD_2005 } & -0.0078 & -0.0076 & -0.0076 & -0.0079 & -0.0076 & -0.0074 \\
\hline & $(0.0113)$ & $(0.0113)$ & $(0.0113)$ & $(0.0115)$ & $(0.0114)$ & $(0.0114)$ \\
\hline \multirow[t]{2}{*}{ YD_2006 } & $0.0154 * *$ & $0.0154^{* *}$ & $0.0149 * *$ & $0.0164 * *$ & $0.0166 * *$ & $0.0165 * *$ \\
\hline & (0.0069) & $(0.0070)$ & $(0.0068)$ & $(0.0074)$ & $(0.0074)$ & $(0.0072)$ \\
\hline \multirow[t]{2}{*}{ YD_2007 } & $0.0272 * * *$ & $0.0279 * * *$ & $0.0275 * * *$ & $0.0283 * * *$ & $0.0292^{* * *}$ & $0.0291 * * *$ \\
\hline & $(0.0090)$ & (0.0089) & $(0.0087)$ & $(0.0087)$ & $(0.0084)$ & $(0.0082)$ \\
\hline \multirow[t]{2}{*}{ YD_2008 } & 0.0019 & 0.0024 & 0.0042 & 0.0026 & 0.0033 & 0.0055 \\
\hline & $(0.0093)$ & $(0.0090)$ & $(0.0085)$ & $(0.0099)$ & $(0.0096)$ & $(0.0090)$ \\
\hline \multirow[t]{2}{*}{ YD_2009 } & $0.0163 * *$ & $0.0165^{* *}$ & $0.0167 * * *$ & $0.0173^{* * *}$ & $0.0176^{* * *}$ & $0.0180 * * *$ \\
\hline & $(0.0065)$ & $(0.0064)$ & $(0.0062)$ & $(0.0066)$ & $(0.0065)$ & $(0.0062)$ \\
\hline \multirow[t]{2}{*}{ YD_2010 } & $0.0267 * * *$ & $0.0266^{* * *}$ & $0.0253^{* * *}$ & $0.0278 * * *$ & $0.0277^{* * *}$ & $0.0265^{* * *}$ \\
\hline & $(0.0069)$ & (0.0070) & $(0.0068)$ & $(0.0071)$ & $(0.0072)$ & $(0.0069)$ \\
\hline \multirow[t]{2}{*}{ YD_2011 } & 0.0105 & 0.0105 & 0.0100 & 0.0115 & 0.0116 & 0.0111 \\
\hline & $(0.0078)$ & $(0.0078)$ & $(0.0078)$ & $(0.0080)$ & (0.0079) & $(0.0079)$ \\
\hline YD_2012 & -0.0100 & -0.0100 & -0.0082 & -0.0098 & -0.0098 & -0.0080 \\
\hline & $(0.0069)$ & $(0.0069)$ & $(0.0065)$ & $(0.0069)$ & $(0.0069)$ & $(0.0066)$ \\
\hline Constant & $0.4599 * * *$ & $0.4684^{* * *}$ & $0.4965 * * *$ & $0.4567 * * *$ & $0.4653^{* * *}$ & $0.4940 * * *$ \\
\hline & $(0.1226)$ & $(0.1241)$ & $(0.1218)$ & $(0.1213)$ & $(0.1234)$ & $(0.1201)$ \\
\hline Observations & 843 & 843 & 843 & 843 & 843 & 843 \\
\hline R-squared & 0.1287 & 0.1294 & 0.1502 & 0.1314 & 0.1323 & 0.1539 \\
\hline No. of firms & 103 & 103 & 103 & 103 & 103 & 103 \\
\hline
\end{tabular}

Note: Robust standard errors are in brackets. ${ }^{* *}$ denotes $1 \%$ significance, ${ }^{* *}$ for $5 \%$ and $*$ for $10 \%$. YD refers to year dummies. Please refer to table 7.2 for the definition of other variables.

Source: Prepared by the authors. 
Given that the measurements of the capital structure may overlap, we have constructed three alternative models. The overall debt-to-asset ratio is not significant and shows that capital structure may not be relevant. When we further divide the gross debt, there are some interesting results. Short-term loans are not good for ROA, but commercial credit has a significantly positive impact on the profitability of firms. Firms which rely more on short-term loans may suffer from stronger constraints and be more affected by interest rate volatility. Given that short-term loans normally require longer periods to realise their full potential, firms may have to give up more profitable projects. Commercial credit is mainly credit between firms. For example, one firm may delay payments to another firm or collect received deposits. It reflects not only a firm's credibility, but also its long-term profitability; therefore, the positive relationship with ROA is not surprising.

It also suggests that the government has a strong influence on the decision-making of state-owned firms or those with a strong state presence in their ownership structures. Therefore, the shares of state ownership have also been included in Figures 7.4 to 7.6 to check this issue. The results are generally positive but insignificant; this indicates that state ownership does not necessarily have any significant impact on the renewable energy sector's performance even though it might have strong influence on the industry's general development. An additional variable related to the ownership structure is also included, representing the importance of the first biggest shareholder. The impacts are also insignificant across all model specifications.

The important things affecting the profitability of China's renewable energy firms are growth potential (measured by the last period growth rate of operation income), the age of the firms listed in the stock market, and the individual firm's size. Firms with better growth potential tend to make more profit; newer listed firms tend to make less profit; and smaller firms tend to make more profit ${ }^{27}$. These results are intuitively sensible. In order to be listed in the stock exchange, firms must show strong potential and this momentum may continue, especially with more capital available when getting listed. Smaller firms with growth potential may be more risky, but they can generate higher returns for investors. Furthermore, significant positive coefficients have been seen in the year dummies in 20062007 and 2009-2010. The first two years positive coefficients are obviously due to the

\footnotetext{
27 It is worth noticing that the interpretation of the size effect only applies to the listed firms. Smaller unlisted firms may behave differently. We thank a referee for this important comment.
} 
passage of REL in 2005. China's stimulus packages in response to the 2008-2009 global financial crisis, which emphasise the role of the renewable energy sector (Zhang, 2008), contribute to the positive coefficients in 2009-2010.

\subsection{Firms' position in the industrial chain}

Arguably, downstream firms should behave differently from upstream firms. ${ }^{28}$ China's renewable energy firms, as described in Table A2 (appendix), mainly concentrate on raw materials and equipment manufacturing (upstream). There are 71 firms in this group, accounting for around two-thirds of all renewable energy firms. If we add those with mixed production lines, this share increases to about $88 \%$. The distribution of these firms creates trouble when negative shocks arrive. For example, the anti-dumping duty and decreased demand from the EU and the US in 2012 have significantly shaken the renewable energy sector. If we consider China's non-listed firms (which are generally smaller and more likely to concentrate on upstream of the industrial chain) the significant negative impact of the international shock is not surprising at all. Developing the renewable energy sector following this strategy may also be problematic since the upstream firms normally have lower levels of technology and thus lower profit margins (relative to the downstream firms). The lower entry barrier to this group can easily cause irrational overinvestment or intensive competition, essentially squashing out the profit.

In this subsection, we test the overinvestment hypothesis and role of capital structure following exactly the same strategy as the previous two subsections. Similar to model (6) in Table 7.3, we replace the industrial dummies in the interaction terms with upstream dummies, mixed dummies, and downstream dummies. All other control variables and econometric setups remain the same. The interaction term coefficients of these new dummy variables with $\mathrm{CFK}^{*} \mathrm{I}(\mathrm{OIG}(\mathrm{t}-1)<0)$ are $0.4344(0.4122), 0.2927(0.9133)$ and $0.5287^{* * *}(0.1943)^{29}$ for upstream, downstream, and mixed, respectively. The fact that the mixed coefficient is the only significant one suggests that only mixed firms (with materials, equipment, and appliance production) have irrational expansion (overinvestment even when there are no clear growth opportunities when free cash flows are available). The

\footnotetext{
${ }^{28}$ We would like to thank the participants of the ERIA work group meetings for their invaluable comments and suggestions for dividing firms according to their positions in the industrial chain. This enables us to provide more insightful information to the questions in this paper.

29 The robust standard errors are in brackets and ${ }^{* *}$ represents a $1 \%$ level of significance.
} 
interesting result is that neither the downstream firms nor the upstream firms have overinvestment problems. Firms that tend to have overinvested problem if their business cover both upstream and downstream in the industrial chain.

Table 7.5 reports the role of capital structure in upstream, mixed, and downstream firms' positions in the renewable industrial chain. It is clear that we can see quite significant differences between these three types of firms. The results of these upstream firms are very similar to the general conclusions in the previous section; the short-term loan is shown to be negative but insignificant. For the other two groups of firms, however, capital structure (or more specifically, the source of financing) matters. For mixed firms, commercial credit is no longer significant. These firms have combined the upstream and the downstream into one group. Commercial credit, which normally applies to firms trading with their partners either upstream or downstream, is now within the firms and therefore has no significant impact.

The role of capital structure for downstream firms is statistically significant. There are more factors shown to have significant impacts on firms' profitability. First, higher levels of debt financing (relative to equity financing) can increase profitability. In examining subcategories of debt financing, we find that the impacts from current liabilities and shortterm loans are insignificant, whereas others are all significantly associated with higher ROA levels. This information provides important policy implications for Chinese policymakers. The accessibility to various channels of debt financing can improve the profitability of downstream firms, consequentially benefiting the development of these firms. Therefore, it is necessary for the authorities to provide supporting financial policies when restructuring China's renewable energy industry towards a more balanced and advanced status. 
Table 7.5: The Role of Capital Structure in Different Firms' Positions

\begin{tabular}{|c|c|c|c|c|c|c|c|c|c|}
\hline & \multicolumn{3}{|c|}{ Upstream } & \multicolumn{3}{|c|}{ Mixed } & \multicolumn{3}{|c|}{ Downstream } \\
\hline & $\begin{array}{l}\text { Model } \\
\text { (u1) }\end{array}$ & $\begin{array}{l}\text { Model } \\
\text { (u2) }\end{array}$ & $\begin{array}{l}\text { Model } \\
\text { (u3) }\end{array}$ & $\begin{array}{l}\text { Model } \\
\text { (m1) }\end{array}$ & $\begin{array}{l}\text { Model } \\
(\mathrm{m} 2)\end{array}$ & $\begin{array}{l}\text { Model } \\
(\mathrm{m} 3)\end{array}$ & $\begin{array}{l}\text { Model } \\
\text { (d1) }\end{array}$ & $\begin{array}{l}\text { Model } \\
\text { (d2) }\end{array}$ & $\begin{array}{l}\text { Model } \\
\text { (d3) }\end{array}$ \\
\hline \multirow[t]{2}{*}{$\mathrm{DTA}(\mathrm{t}-1)$} & 0.0272 & & & -0.0120 & & & $0.0382 *$ & & \\
\hline & (0.0167) & & & $(0.0080)$ & & & (0.0200) & & \\
\hline \multirow[t]{2}{*}{$\mathrm{CTA}(\mathrm{t}-1)$} & & 0.0289 & & & $-0.0386 * *$ & & & 0.0110 & \\
\hline & & $(0.0174)$ & & & $(0.0145)$ & & & $(0.0174)$ & \\
\hline \multirow[t]{2}{*}{$\operatorname{NCTA}(t-1)$} & & 0.0165 & & & 0.0123 & & & $0.0792^{* *}$ & \\
\hline & & $(0.0406)$ & & & (0.0167) & & & $(0.0273)$ & \\
\hline \multirow[t]{2}{*}{$\mathrm{BTA}(\mathrm{t}-1)$} & & & -0.0335 & & & -0.1171 & & & $0.1213^{* * *}$ \\
\hline & & & $(0.0970)$ & & & $(0.0916)$ & & & $(0.0376)$ \\
\hline \multirow[t]{2}{*}{$\operatorname{CRTA}(t-1)$} & & & $0.0689 *$ & & & -0.0278 & & & $0.0624 * * *$ \\
\hline & & & $(0.0367)$ & & & $(0.0394)$ & & & $(0.0166)$ \\
\hline \multirow[t]{2}{*}{ SLTA(t-1) } & & & -0.0254 & & & $-0.0606 *$ & & & -0.0236 \\
\hline & & & $(0.0385)$ & & & $(0.0320)$ & & & $(0.0294)$ \\
\hline \multirow[t]{2}{*}{$\operatorname{LLTA}(\mathrm{t}-1)$} & & & 0.0104 & & & 0.0106 & & & $0.0505^{* *}$ \\
\hline & & & (0.0331) & & & $(0.0164)$ & & & $(0.0232)$ \\
\hline \multirow[t]{2}{*}{ OIG(t-1) } & $0.0330 * * *$ & $0.0329 * * *$ & $0.0269 * *$ & 0.0119 & 0.0140 & $0.0124 *$ & 0.0170 & 0.0185 & 0.0162 \\
\hline & (0.0097) & (0.0098) & (0.0109) & $(0.0082)$ & $(0.0081)$ & $(0.0070)$ & $(0.0251)$ & $(0.0253)$ & $(0.0274)$ \\
\hline \multirow[t]{3}{*}{ Age } & $0.0037^{*}$ & $0.0038^{*}$ & $0.0036^{*}$ & -0.0017 & -0.0016 & -0.0015 & 0.0014 & 0.0005 & 0.0014 \\
\hline & $(0.0022)$ & $(0.0022)$ & $(0.0021)$ & $(0.0018)$ & (0.0018) & (0.0017) & $(0.0022)$ & $(0.0023)$ & $(0.0021)$ \\
\hline & - & - & - & & & & & & \\
\hline \multirow[t]{2}{*}{ SZ } & $0.0233^{* * *}$ & $0.0232 * * *$ & $0.0245 * * *$ & 0.0002 & -0.0031 & 0.0008 & -0.0206 & -0.0212 & $-0.0300 * *$ \\
\hline & $(0.0084)$ & $(0.0083)$ & $(0.0083)$ & $(0.0103)$ & (0.0102) & (0.0095) & $(0.0135)$ & $(0.0143)$ & $(0.0125)$ \\
\hline \multirow[t]{2}{*}{ YD_2003 } & 0.0260 & 0.0260 & 0.0263 & 0.0002 & 0.0010 & 0.0033 & 0.0006 & -0.0010 & -0.0036 \\
\hline & (0.0190) & (0.0190) & $(0.0188)$ & $(0.0063)$ & $(0.0060)$ & $(0.0056)$ & $(0.0146)$ & $(0.0147)$ & (0.0163) \\
\hline \multirow[t]{2}{*}{ YD_2004 } & $0.0292^{*}$ & $0.0291^{*}$ & 0.0274 & -0.0083 & -0.0095 & -0.0092 & -0.0460 & -0.0443 & -0.0482 \\
\hline & (0.0167) & (0.0168) & (0.0168) & (0.0079) & (0.0081) & (0.0093) & $(0.0392)$ & $(0.0380)$ & $(0.0392)$ \\
\hline \multirow[t]{2}{*}{ YD_2005 } & 0.0013 & 0.0010 & 0.0019 & -0.0123 & $-0.0142^{*}$ & -0.0133 & $-0.0268^{*}$ & -0.0209 & $-0.0253^{*}$ \\
\hline & (0.0205) & $(0.0203)$ & (0.0204) & $(0.0078)$ & (0.0075) & $(0.0087)$ & $(0.0133)$ & $(0.0124)$ & (0.0137) \\
\hline \multirow[t]{2}{*}{ YD_2006 } & $0.0303 * *$ & $0.0301 * *$ & $0.0287 * *$ & 0.0016 & 0.0012 & -0.0002 & -0.0027 & 0.0010 & -0.0022 \\
\hline & $(0.0116)$ & (0.0115) & $(0.0114)$ & $(0.0073)$ & (0.0075) & $(0.0078)$ & $(0.0121)$ & $(0.0114)$ & $(0.0103)$ \\
\hline \multirow[t]{3}{*}{ YD_2007 } & $0.0387^{* *}$ & $0.0381^{* *}$ & $0.0368 * *$ & 0.0014 & 0.0024 & -0.0004 & 0.0176 & $0.0226^{* *}$ & $0.0253^{* * *}$ \\
\hline & $(0.0151)$ & $(0.0148)$ & (0.0147) & $(0.0092)$ & (0.0094) & $(0.0091)$ & $(0.0115)$ & $(0.0098)$ & $(0.0082)$ \\
\hline & & & & - & - & - & & & \\
\hline \multirow[t]{2}{*}{ YD_2008 } & $0.0234^{*}$ & $0.0231^{*}$ & $0.0237^{*}$ & $0.0602 * * *$ & $0.0567^{* * *}$ & $0.0583^{* * *}$ & 0.0130 & 0.0177 & 0.0176 \\
\hline & $(0.0132)$ & (0.0129) & $(0.0120)$ & $(0.0113)$ & $(0.0108)$ & (0.0109) & $(0.0117)$ & $(0.0112)$ & (0.0104) \\
\hline \multirow[t]{2}{*}{ YD_2009 } & $0.0254 * *$ & $0.0252 * *$ & $0.0233^{* *}$ & -0.0104 & -0.0086 & -0.0096 & $0.0197^{*}$ & $0.0220 * *$ & $0.0221 * *$ \\
\hline & $(0.0102)$ & (0.0101) & (0.0099) & $(0.0068)$ & $(0.0067)$ & $(0.0066)$ & (0.0097) & $(0.0094)$ & $(0.0082)$ \\
\hline YD_2010 & $0.0371^{* * *}$ & $0.0374 * * *$ & $0.0345^{* * *}$ & -0.0163 & -0.0140 & -0.0160 & $0.0421^{* *}$ & $0.0450^{* *}$ & $0.0459 * *$ \\
\hline & $(0.0088)$ & $(0.0091)$ & $(0.0088)$ & $(0.0128)$ & (0.0125) & $(0.0122)$ & $(0.0170)$ & (0.0177) & $(0.0172)$ \\
\hline YD_2011 & $0.0208^{*}$ & $0.0207^{*}$ & $0.0194 *$ & -0.0203 & -0.0200 & $-0.0232 *$ & 0.0069 & 0.0094 & 0.0133 \\
\hline & $(0.0108)$ & $(0.0107)$ & $(0.0106)$ & $(0.0136)$ & $(0.0135)$ & $(0.0120)$ & (0.0198) & $(0.0197)$ & $(0.0203)$ \\
\hline YD_2012 & -0.0065 & -0.0066 & -0.0051 & -0.0057 & -0.0055 & -0.0048 & -0.0289 & -0.0283 & -0.0260 \\
\hline & $(0.0081)$ & (0.0081) & $(0.0075)$ & $(0.0087)$ & $(0.0088)$ & $(0.0086)$ & $(0.0278)$ & $(0.0272)$ & $(0.0267)$ \\
\hline Constant & $0.4514 * * *$ & $0.4477 * * *$ & $0.4844 * * *$ & 0.0661 & 0.1394 & 0.0522 & 0.4304 & 0.4596 & $0.6420 * *$ \\
\hline & $(0.1676)$ & $(0.1646)$ & $(0.1619)$ & $(0.2155)$ & $(0.2133)$ & $(0.2002)$ & $(0.2719)$ & $(0.2915)$ & $(0.2522)$ \\
\hline Observations & 515 & 515 & 515 & 185 & 185 & 185 & 143 & 143 & 143 \\
\hline R-squared & 0.1703 & 0.1705 & 0.1849 & 0.3511 & 0.3790 & 0.4051 & 0.2424 & 0.2542 & 0.2697 \\
\hline No. of firms & 69 & 69 & 69 & 17 & 17 & 17 & 17 & 17 & 17 \\
\hline
\end{tabular}

Note: Robust standard errors are in brackets. ${ }^{* * *}$ denotes $1 \%$ significance, ${ }^{* *}$ for $5 \%$ and $*$ for $10 \%$. It is worth noting that our sample is unbalanced. Some variables (especially financial variables) are missing for some firms, therefore, the effective sample (even with the same number of firms) used in each regression differ from each other. YD refers to year dummies. Please refer to table 7.2 for the definition of other variables. Source: Prepared by the authors. 


\section{Conclusion and policy implications}

China's investment in the renewable energy sector has grown rapidly since 2006 when REL was implemented. Motivated by the desire to solve its long-standing environmental problems and energy security concerns, the Chinese government in recent years has strongly encouraged the development of the renewable energy sector and is now the world's top investor in this area. When the EU and the US, the market leaders, began to slow down and implement a series of new policies in recent years, especially towards products from China, China's growth has slowed down. Problems have arisen as a consequence of fast expansion.

Despite the setback of global investment in renewable energy, this sector still has a promising future. Based on the estimations of most major agencies (for example, IEA, 2009), the total investment in the renewable energy sector across the world has the potential to be worth billions or even trillions of dollars over the next couple of decades. As China determines to keep the pace of its rapid growth in the renewable energy sector, it is important to evaluate this industry's efficiency and problems, especially from a micro perspective. This paper adopts the standard finance approach to investigate the problem of firms overinvesting in the renewable energy sector.

Our results show that overinvestment in the renewable energy sector exists. It was first captured by the positive and significant autoregressive investment coefficients, indicating strong momentum that exists in this industry. Secondly, the investment in renewable energy sector has shown to have patterns over our sample period. The passage of REL and other favourable policies in China has indeed triggered a significant desire for investment in this sector. The effects mainly occurred between 2007 and 2011, consistent with the changing international environment. The key results based on the Jensen's (1986) free cash flow hypothesis demonstrate that firm managers may act irrationally when free cash flows are available. They tend to invest even when future growth opportunities are not positive and their investment decisions are at the cost of shareholders' benefits. Among all four sectors, this kind of irrational overinvestment has been more significant in the biomass and wind sectors.

Consistent with the Modigliani and Miller (1958) theorems, capital structure does not seem relevant to the renewable energy sector if we use the aggregate debt-to-asset 
ratio as the measure. Categorising debt according to its different forms reveals more interesting information. Capital structure does matter, such as commercial credit and shortterm loans.

Given the concerns over environmental changes and the responses from firms in different positions on the renewable energy industrial chain, our empirical results are based on categorising firms into upstream, downstream, and mixed groups. Our results show that one's position in the industrial chain matters both in terms of overinvestment and the role of capital structure. In the transition process, mixed firms tend to experience overinvestment or irrational expansion, clearly requiring policymakers to intervene or provide proper guidance. Capital structure turns out to be more important to those downstream firms, indicating that policymakers may provide further financial support that enables these firms to finance their investments through corporate bonds, commercial credit, or long-terms debts.

Both investment in the renewable energy sector and returns have shown clear cyclical behaviour. For example, after the 2008 global financial crisis, renewable energy sector in China has become a new concept of potential driving forces for its economic growth. The consequence of policy supports and investors' interest has brought significant increase in the renewable energy investment. However, our data have shown that the rapid progress of China's renewable energy sector mainly concentrates in the upstream (raw material and equipment manufacturing). The unbalanced industrial structure and potential internal over-competition have resulted in clear vulnerability against outside shocks. Policy supports should aim to encourage structural reform of the renewable energy sector, which shifts the industry towards high-end technological advance and development.

\section{References}

Arellano, M. and S.R. Bond, (1991), 'Some Tests of Specification of Panel Data: Monte Carlo Evidence and an Application to Employment Equations', Review of Economic Studies, (58), pp.277-297.

Arellano, M. and O. Bover (1995), 'Another Look at the Instrumental-variable Estimation of Error Component Models', Journal of Econometrics, (68), pp.29-52.

Banerjee, A. (1992), 'A Simple Model of Herd Behavior', Quarterly Journal of Economics, 107(3), pp.797-817.

Blundell, R. and S. Bond (1998), 'Initial Conditions and Moment Restrictions in Dynamic 
Panel Data Models', Journal of Econometrics, 87, pp.115-143.

Burer, M.J. and R. Wustenhagen (2008), 'Cleantech Venture Investors and Energy Policy Risk: An Exploratory Analysis of Regulatory Risk Management Strategies', in R. Wustenhagen, J. Hamschmidt, S. Sharma, and M. Starik (eds), Sustainable Innovation and Entrepreneurship. Cheltenham, UK: Edward Elgar Publishing, pp.290-309.

Caralis, G., D. Diakoulaki, P. Yang, Z. Gao, A. Zervos, and K. Rados (2014), 'Profitability of Wind Energy Investments in China using a Monte Carlo Approach for the Treatment of Uncertainties', Renewable and Sustainable Energy Reviews, 40, pp.224-236.

Corsatea, T.D., S. Giaccaria, and R.L. Arántegui (2014), 'The Role of Sources of Finance on the Development of Wind Technology', Renewable Energy, 66, pp.140-149.

De Jager, D. and M. Rathmann (2008), Policy Instrument Design to Reduce Financing Costs in Renewable Energy Technology Projects. Utrecht, the Netherlands: Ecofys.

Ding, S., A. Guariglia and J. Knight (2010), 'Does China Overinvest? Evidence from a Panel of Chinese Firms', Department of Economics Discussion Paper No. 2010-32, University of Glasgow.

Dinica, V. (2006), 'Support Systems for the Diffusion of Renewable Energy Technologies an Investor Perspective', Energy Policy, 34, pp.461-480.

Economic Research Institute for ASEAN and East Asia (2012). Economic Impact Evaluation of Investments on the Energy Savings and Low-carbon Emitting Technologies in East Asia. Available at: http://www.eria.org/research/energy/economic-impact-evaluation-of-investmentson-the-energy-savings-and-low-carbon-emitting-technologies.html

Gilchrist, S. and C.P. Himmelberg (1995), 'Evidence on the role of cash flow for investment', Journal of Monetary Economics, 36, pp. 541-572.

Greenspan, A., (1996). Minutes of the Federal Open Market Committee. Available at: http://www.federal.reserve.gov/transcript/1996/19960924meeting.pdf (24/Sep/1996).

Grubb, M.J. (2004), 'Technology Innovation and Climate Policy, an Overview of Issues and Options', Keio Economic Studies, 41, pp.103-132.

Hamilton, K. (2009), 'Unlocking Finance for Clean Energy: The Need for "Investment Grade" Policy', Energy, Environment and Development Programme Paper No. 09/04, Renewable Energy Finance Project, London: Chatham House.

International Energy Agency (IEA) (2009), World Energy Outlook. Paris: OECD/IEA.

International Panel on Climate Change (IPCC) (2011), 'Policy, Financing and Implementation', in Edenhofer, O., R. PichsMadruga, Y. Sokona, K. Seyboth, P. Matschoss, S. Kadner, T. Zwickel, P. Eickemeier, G. Hansen, S. Schlomer, and C. von Stechow (eds), IPCC Special Report on Renewable Energy Sources and Climate Change Mitigation. Cambridge, United Kingdom and New York, NY, USA: Cambridge University Press.

International Renewable Energy Agency (IRENA) (2014a), Renewable Energy Prospects: China, REmap 2030 analysis. IRENA: Abu Dhabi. Available at: www.irena.org/remap (June/2014).

International Renewable Energy Agency (IRENA) (2014b), REthinking Energy: Towards a New Power System. IRENA: Abu Dhabi. Available at: www.irena.org/rethinking (September/2014)

Jensen, M.C. (1986), 'Agency Costs of Free Cash Flow, Corporate Finance, and Takeovers', 
American Economic Review, 76, pp.323-329.

Lang, L.H.P., and R.H. Litzenberger (1989), 'Dividend Announcements, Cash Flow Signaling VS. Free Cash Flow Hypothesis?', Journal of Financial Economics, 24, pp.181-191.

Lang, L.H.P., R.M. Stulz, and R.A. Walkling (1991), 'A Test of the Free Cash Flow Hypothesis, the Case of Bidder Returns', Journal of Financial Economics, 29, pp.315-335.

Lin B. and L. Yang (2014), 'Efficiency Effect of Changing Investment Structure on China's Power Industry', Renewable and Sustainable Energy Reviews, 39, pp.403-411.

Liu, X. (2013), 'The Value of Holding Scarce Wind Resource - A Cause of Overinvestment in Wind Power Capacity in China', Energy Policy, 63, pp.97-100.

McConnell J.J. and C.J. Muscarella (1986), 'Corporate Capital Expenditure Decisions and the Market Value of the Firm', Journal of Financial Economics, 14, pp.399-422.

Modigliani, F. and M. Miller (1958), 'The Cost of Capital, Corporation Finance and the Theory of Investment', American Economic Review, 48, pp.261-297.

Olmos, Luis, S. Ruester, and S. Liong (2012), 'On the Selection of Financing Instruments to Push the Development of New Technologies: Application to Clean Energy Technologies', Energy Policy, 43, pp.252-266.

Peters, G.P., R.M. Andrew, T. Boden, J.G. Canadell, P. Ciais, C. Le Quéré, G. Marland, M.R. Raupach, and C. Wilson (2013), 'The Challenge to Keep Global Warming Below $2{ }^{\circ} \mathrm{C}$ ', Nature Climate Change, 3, pp. 4-6.

Popp, D. (2010), 'Innovation and Climate Policy, in C. Gordon, V. Rausser, K. Smith, and D. Zilberman (eds.) Annual Review of Resource Economics, 2. Palo Alto, CA: Annual Reviews, pp.275-298.

Qiu, H., L. Sun, J. Huang, and S. Rozellec (2012), 'Liquid Biofuels in China: Current Status, Government Policies, and Future Opportunities and Challenges', Renewable and Sustainable Energy Reviews, 16, pp.3095-3104.

Shen, J. and C. Luo (2015), 'Overall Review of Renewable Energy Subsidy Policies in China - Contradictions of Intentions and Effects', Renewable and Sustainable Energy Reviews, 41, pp.1478-1488.

Shiller, R. J. (2000), Irrational Exuberance. Princeton University Press.

Tan, X.M. (2013), 'China's Overseas Investment in the Energy/resources Sector: Its Scale, Drivers, Challenges and Implications', Energy Economics, 36, pp.750-758.

Wang, Q. (2010), 'Effective Policies for Renewable energy - The Example of China's Wind Power - Lessons for China's Photovoltaic Power', Renewable and Sustainable Energy Reviews, 14, pp.702-712.

Wang, F., H. Yin and S. Li (2010), 'China's Renewable Energy Policy: Commitments and Challenges', Energy Policy, 38, pp.1872-2878.

Wustenhagen, R. and E. Menichetti (2012), 'Strategic Choices for Renewable Energy Investment: Conceptual Framework and Opportunities for Further Research', Energy Policy, 40, pp.1-10.

Wustenhagen, R., M. Wolsink, and M.J. Burer (2007), 'Social Acceptance of Renewable Energy Innovation: An Introduction to the Concept', Energy Policy, 35, pp.26832691.

Zeng, M., X. Liu, Y. Li, and L. Peng (2014), 'Review of Renewable Energy Investment and Financing in China: Status, Mode, Issues and Countermeasures', Renewable and 
Sustainable Energy Reviews, 31, pp.23-37.

Zeng, M., K. Zhang, and J. Dong (2013), 'Overall Review of China's Wind Power Industry: Status Quo, Existing Problems and Perspective for Future Development', Renewable and Sustainable Energy Reviews, 24, 379-386.

Zhang, G.B. (2008), 'The Current Energy Status: Crisis and Opportunity' (in Chinese). Available at: http://scitech.people.com.cn/GB/8591346.html

Zhang, M., D. Zhou, and P. Zhou (2014), 'A Real Option Model for Renewable Energy Policy Evaluation with Application to Solar PV Power Generation in China', Renewable and Sustainable Energy Reviews, 40, pp.944-955.

Zhang, P., Y. Yang, J. Shi, Y. Zheng, L. Wang, and X. Li (2009), 'Opportunities and Challenges for Renewable Energy Policy in China', Renewable and Sustainable Energy Reviews, 13, pp.439-449.

Zhao R., G. Shi, and H. Chen (2011), 'Present Status and Prospects of Photovoltaic Market in China', Energy Policy, 39, pp.2204-2207.

Zhao X., T. Feng, L. Cui, and X. Feng (2014), 'The Barriers and Institutional Arrangements of the Implementation of Renewable Portfolio Standard: A Perspective of China', Renewable and Sustainable Energy Reviews, 30, pp.371-380.

Zhao, X., G. Wan, and Y. Yang (2015), 'The Turning Point of Solar Photovoltaic Industry in China: Will it Come?', Renewable and Sustainable Energy Reviews, 41, pp.178188. 


\section{Appendix}

Table A1: Descriptive Statistics for Four Sub-sectors

\begin{tabular}{lcccccccc}
\hline & \multicolumn{2}{c}{ Wind } & \multicolumn{2}{c}{ Nuclear } & \multicolumn{2}{c}{ Biomass } & \multicolumn{2}{c}{ Solar } \\
\hline Notation & Mean & SD. & Mean & SD. & Mean & SD. & Mean & SD. \\
\hline IK & 0.4443 & 1.1342 & 0.4656 & 0.6452 & 0.6236 & 2.1708 & 0.6052 & 0.8612 \\
CFK & 0.3913 & 0.6760 & 0.6519 & 1.2312 & 0.3411 & 0.5611 & 0.3114 & 0.4444 \\
OCF & 0.1266 & 0.9668 & 0.0918 & 1.4869 & 0.3069 & 1.1000 & 0.1193 & 0.4861 \\
DTA & 0.6528 & 0.3335 & 0.6234 & 0.3163 & 0.6044 & 0.2525 & 0.6154 & 0.2866 \\
CTA & 0.4540 & 0.2783 & 0.5199 & 0.3042 & 0.4380 & 0.2226 & 0.4773 & 0.2222 \\
NCTA & 0.1989 & 0.2205 & 0.1035 & 0.1175 & 0.1664 & 0.1693 & 0.1381 & 0.1481 \\
SLTA & 0.1535 & 0.1270 & 0.1534 & 0.1371 & 0.1968 & 0.1511 & 0.2244 & 0.1419 \\
LLTA & 0.1650 & 0.2142 & 0.0698 & 0.1097 & 0.1375 & 0.1585 & 0.0969 & 0.1335 \\
BTA & 0.0170 & 0.0425 & 0.0092 & 0.0361 & 0.0188 & 0.0467 & 0.0177 & 0.0557 \\
CRTA & 0.2102 & 0.2670 & 0.2860 & 0.2778 & 0.1612 & 0.1622 & 0.1818 & 0.1278 \\
TQ & 1.7136 & 0.8632 & 2.1254 & 1.2258 & 1.6088 & 0.6688 & 1.9459 & 1.0272 \\
SZ & 22.470 & 1.3954 & 21.826 & 1.3903 & 22.159 & 1.2136 & 21.904 & 0.9307 \\
ROA & 0.0294 & 0.0528 & 0.0386 & 0.0441 & 0.0260 & 0.0501 & 0.0180 & 0.0640 \\
OIG & 0.1626 & 0.3189 & 0.1755 & 0.2904 & 0.1341 & 0.2677 & 0.1480 & 0.3742 \\
AGE & 9.9245 & 5.3409 & 8.5105 & 4.9971 & 9.5580 & 4.6056 & 7.6382 & 4.4634 \\
State & 21.074 & 27.006 & 18.585 & 25.357 & 22.241 & 24.281 & 11.798 & 20.343 \\
FOWN & 39.464 & 16.746 & 40.810 & 16.229 & 36.156 & 15.176 & 35.284 & 14.470 \\
\hline SOIC & & &
\end{tabular}

Sources: RESSET database and authors' calculation. Please refer to table 7.2 for the definition of other variables.

Table A2: Descriptive Statistics for Three Stages of Production

\begin{tabular}{lcccccc}
\hline & \multicolumn{2}{c}{$\begin{array}{c}\text { Material } \\
\text { (No. of Firms = 71) }\end{array}$} & \multicolumn{2}{c}{$\begin{array}{c}\text { Generator/Final Users } \\
\text { (No. of Firms = 17) }\end{array}$} & \multicolumn{2}{c}{$\begin{array}{c}\text { Mixed } \\
\text { (No. of Firms = 18) }\end{array}$} \\
\hline Notation & Mean & SD. & Mean & SD. & Mean & SD. \\
\hline IK & 0.5669 & 1.3025 & 0.4117 & 1.3176 & 0.5775 & 0.9567 \\
CFK & 0.4728 & 0.9713 & 0.3251 & 0.5143 & 0.3911 & 0.6186 \\
OCF & 0.0848 & 1.2891 & 0.2386 & 0.4034 & 0.1562 & 0.5803 \\
DTA & 0.5928 & 0.2943 & 0.6819 & 0.3224 & 0.6295 & 0.2658 \\
CTA & 0.4999 & 0.2632 & 0.3498 & 0.1899 & 0.4943 & 0.2142 \\
NCTA & 0.0928 & 0.1077 & 0.3320 & 0.2371 & 0.1352 & 0.1488 \\
SLTA & 0.1891 & 0.1453 & 0.1446 & 0.1224 & 0.2224 & 0.1386 \\
LLTA & 0.0608 & 0.0955 & 0.3008 & 0.2279 & 0.0871 & 0.1277 \\
BTA & 0.0094 & 0.0341 & 0.0234 & 0.0498 & 0.0299 & 0.0750 \\
CRTA & 0.2361 & 0.2154 & 0.0948 & 0.1001 & 0.2137 & 0.1644 \\
TQ & 1.9980 & 1.0231 & 1.5564 & 0.7421 & 2.0265 & 1.3199 \\
SZ & 21.6413 & 1.0855 & 22.8666 & 1.2960 & 21.9971 & 1.0114 \\
ROA & 0.0229 & 0.0570 & 0.0391 & 0.0440 & 0.0223 & 0.0563 \\
OIG & 0.1361 & 0.3395 & 0.1984 & 0.2581 & 0.1513 & 0.3306 \\
AGE & 7.8537 & 4.6212 & 10.258 & 4.8527 & 9.6912 & 5.4874 \\
State & 15.062 & 22.892 & 24.311 & 26.378 & 11.423 & 20.887 \\
FOWN & 37.431 & 15.441 & 37.830 & 16.166 & 34.121 & 14.575 \\
\hline
\end{tabular}

Source: RESSET database and authors' calculation. Please refer to table 7.2 for the definition of other variables. 